\title{
PENGARUH STORE ENVIRONMENT TERHADAP RESPON EMOSI POSITIF DAN IMPULSE BUYING YANG DIMODERASI SITUATIONAL FACTOR
}

\author{
I Made Agus Indrawan ${ }^{1}$ \\ Ida Bagus Sudiksa ${ }^{2}$
}

\author{
${ }^{1,2}$ Fakultas Ekonomi dan Bisnis Universitas Udayana (Unud), Bali, Indonesia \\ E-mail:indrawanagus16@gmail.com
}

\begin{abstract}
ABSTRAK
Tujuan dari penelitian ini adalah untuk mengidentifikasi faktor-faktor yang secara signifikan mempengaruhi impulse buying atau pembelian tanpa rencana yaitu faktor store environment, respon emosi positif, serta situational faktor. Sampel penelitian sebanyak 90 orang responden (konsumen) Ramayana Mall Denpasar. Metode pengumpulan data dilakukan melalui penyebaran kuisioner dan teknik analisis yang digunakan adalah regresi linier sederhana dan Moderated Regression Analysis (MRA).Berdasarkan hasil analisis ditemukan bahwa store environment memiliki pengaruh positif dan signifikan terhadap respon emosi positif, respon emosi positif memiliki pengaruh yang positif dan signifikan terhadap perilaku impulse buying, dan situational factor memperkuat pengaruh respon emosi positif terhadap perilaku impulse buying.
\end{abstract}

Kata Kunci: store environment, respon emosi positif, impulse buying, situational factor

\begin{abstract}
The purpose of this study is to identify factors that significantly affect unplanned impulse buying or buying, namely store environment factors, positive emotional responses, and situational factors. Research samples were 90 respondents (consumers) of Ramayana Mall Denpasar. Methods of data collection carried out through questionnaires and analysis techniques used are simple linear regression and Moderated Regression Analysis (MRA). Based on the results of the analysis found that store environment has a positive and significant influence on positive emotional response, positive emotional response has a positive and significant influence on the behavior of impulse buying, and situational factors strengthen the influence of positive emotional responses to impulse buying behavior.
\end{abstract}

Keywords: store environment, positive emotional response, impulse buying, situational factor 


\section{PENDAHULUAN}

Perkembangan jaman yang semakin pesat membuat bisnis dalam industri yang sama bersaing secara lebih kompetitif untuk mendapatkan pangsa pasar yang besar dan memenangkan persaingan bisnis. Banyak cara yang dilakukan perusahaan untuk menarik perhatian konsumen pada produk atau jasa layanan perusahaan. Perhatian pada lingkungan toko dan menciptakan respon emosi positif merupakan beberapa cara yang dapat dilakukan perusahaan untuk menarik konsumen untuk bersedia membeli produk atau jasa layanan perusahaan (Chang et al., 2013). Kemampuan perusahaan untuk memberikan stimuli tentunya akan memberikan dampak pada pengambilan keputusan pembelian konsumen. Termasuk yang tanpa direncanakan atau impulse buying. Tampilan toko, produk dan layanan yang baik akan lebih menarik dan meningkatkan keinginan konsumen berkunjung pada toko yang bersangkutan. Hal ini berpengaruh terhadap keinginan konsumen untuk membeli produk tanpa direncanakan sebelumnya karena melihat adanya toko-toko yang menarik.

Banyak faktor yang mempengaruhi konsumen membeli produk secara langsung tanpa direncanakan terlebih dahulu. Faktor tersebut seperti tatanan layout toko, musik yang diputar dalam toko, situasi dari dalam toko, penerangan/cahaya, pegawai yang bekerja maupun produk yang dijual. Karakteristik lingkungan toko seperti musik dan cahaya memiliki efek pada konsumen yang berdampak positif yang mana, pada gilirannya, berpengaruh terhadap impulse buying (Mohan et al., 2013). 
Saat konsumen tertarik untuk masuk atau berkunjung pada suatu toko, pihak manajemen juga harus mampu mengolah emosi konsumen menuju pada emosi yang positif. Respon emosi konsumen yang positif terhadap lingkungan toko berpengaruh terhadap perilaku konsumen secara tiba-tiba atau pembelian tanpa direncanakan. Pada umumnya, konsumen tertarik pada toko yang terlihat unik dan menarik dari luar dan kemudian baru masuk ke dalam toko untuk mengetahui lebih jauh tentang produk yang ditawarkan. Konsumen dengan emosi positif akan dengan segera membeli produk yang dilihatnya secara spontan.

Selain dua faktor tersebut, ada faktor lain yang memberikan kontribusi pada peningkatan pembelian tanpa rencana. Salah satu faktor tersebut adalah faktor berasal dari dalam diri konsumen atau situasional karakteristik (Chang et al., 2013). Hal-hal yang memperkuat pengaruh respon emosi positif konsumen terhadap impulse buying seperti ketersediaan waktu konsumen, ketersediaan uang, dan task definition. Persepsi konsumen dan perilaku konsumen sering diperkuat oleh situasi yang konsumen miliki saat ini.

Konsumen yang melakukan impulse buying dapat diperkuat dengan adanya karakteristik situasional. Adanya ketersediaan waktu, keuangan yang memadai, dan alasan seseorang dalam membeli produk dapat mendorong orang dalam pengambilan keputusan pembelian barang secara impulse. Apakah dan bagaimanakah variabel situasional dapat mempengaruhi perilaku pembelian impulse tentunya menarik untuk diteliti.

Point of Purchase Advertising Institute (POPAI) (dalam Astuti dan Fillippa, 2008) menyebutkan bahwa sekitar 75 persen pembelian di supermarket dilakukan 
secara tak terencana. Data ini juga didukung oleh hasil studi yang dilakukan Coley dan Burgess (2003) yang menyebutkan 50 persen pembeli di Mall berbelanja secara impulsif. Hal ini disebabkan pembelian impulsif merupakan sebuah fenomena dan kecenderungan perilaku berbelanja meluas yang terjadi di dalam pasar dan menjadi poin penting yang mendasari aktivitas pemasaran (Herabadi, 2003). Pembelian impulsif di Indonesia juga terlihat dari hasil survei yang dilakukan oleh AC Nielsen (2012) yang menyatakan bahwa 85 persen konsumen ritel modern di Indonesia cenderung untuk berbelanja secara impulsif. Mengingat besarnya pengaruh pembelian impulsif terhadap total penjualan, maka pemasar perlu untuk mengidentifikasi faktor-faktor penyebabnya untuk dapat memformulasikan strategi pemasaran yang tepat (Hausman, 2000).

Semakin tinggi tingkat kemenarikan pemajangan produk dengan dukungan lingkungan toko yang baik serta kemampuan pemasar untuk menciptakan respon emosi positif akan meningkatkan pengambilan keputusan pembelian termasuk pembelian tanpa rencana. Pembelian tanpa rencana akan semakin besar saat konsumen memiliki karakteristik situasional yang mendukung seperti keterbatasan waktu, kemampuan finansial yang semakin tinggi dan tugas atau peran dari konsumen (Chang et al., 2013).

Masuknya gerai ritel asing ke Indonesia begitu pesat, menguntungkan, dan menjanjikan. Akan tetapi, dengan semakin banyak masuknya ritel asing ke Indonesia akan menjadi ancaman bagi peritel lokal yang sebelumnya sudah lebih dahulu menguasai pasar. Indonesia merupakan negara berkembang yang menjadi target potensial dalam pemasaran produk, baik dari perusahaan lokal maupun 
internasional. Agar perusahaan tersebut menuai kesuksesan di Indonesia, maka perlu mempelajari karakter unik yang dimiliki oleh konsumen Indonesia. Karakter unik dalam hal ini adalah perilaku konsumen yang memiliki ciri khas tersendiri dibandingkan dengan sebagian besar konsumen lain.

Menurut Susanta (2007), sebagian besar konsumen Indonesia memiliki karakter unplanned. Mereka biasanya suka bertindak "last minute”. Jika berbelanja, mereka sering menjadi impulse buyer. Berdasarkan karakteristik tersebut, perusahaan diharapkan dapat mengeluarkan strategi pemasaran yang dapat menunjang perusahaannya. Ketua Harian Asosiasi Pengusaha Ritel Indonesia (Aprindo), Tutum Rahanta, mengatakan industri ritel di Indonesia diperkirakan tumbuh 15 persen setiap tahunnya (bisnis.tempo.co), pernyataan Tutum tersebut menanggapi rencana pembukaan Lotte Department Store di Indonesia akhir tahun 2012. Gerai Lotte Department Store sendiri berasal dari negara Korea Selatan. Tutum menyatakan, dengan pembukaan Lotte Department Store di Indonesia, peta persaingan bisnis ritel semakin ketat. Fenomena impulse buying yang terjadi di toko-toko modern berlaku juga di Kota Denpasar. Salah satu jaringan ritel yang terbesar di Kota Denpasar yaitu Ramayana Mall yang terletak di Jalan Diponegoro No. 103 Denpasar, menyediakan produk sandang yang komplit mulai dari anak-anak hingga ukuran dewasa. Ramayana Mall juga menyediakan berbagai jenis fasilitas pendukung kegiatan belanja. Ramayana ini terdiri dari 4 lantai, lantai 1 dan 2 menjual berbagai macam merk baju, celana, alat cosmetic, dan berbagai macam merk sepatu, di lantai 3 terdapat gerai-gerai makanan apabila konsumen merasa lapar pada saat berbelanja, dan di lantai 4 
terdapat wahana permainan bagi anak, toko buku, dan hiburan lainnya sehingga konsumen yang berbelanja di Ramayana tidak merasa bosan dan dapat membawa serta keluarga. Berkaitan dengan persaingan usaha ritel yang semakin ketat, merupakan suatu keharusan bagi Ramayana Mall Denpasar melakukan efisiensi strategi pemasaran guna memenangkan pasar.

Alasan memilih lokasi penelitian di Ramayana Mall Denpasar dikarenakan Mall tersebut masih sedikit yang meneliti dan juga Ramayana Mall berbeda dengan pesaing ritel lainnya di Denpasar seperti Matahari Department Store, Mall Bali Galeria, maupun Robinson yang mematok harga untuk kalangan menengah kebawah. Hal itu mendukung para konsumen untuk berbelanja pakaian yang murah tapi tidak kalah bagus dengan mall lain yang ada di Denpasar. Dengan alasan ini, impulse buying konsumen sudah pasti banyak akan terjadi di Ramayana Mall Denpasar dengan didukung emosi positif yang ditimbulkan dari store environment dan fasilitas yang tidak kalah nyaman dengan Mall pesaing lainnya. Berbagai usaha telah dilakukan manajemen Ramayana Denpasar untuk mengambil hati konsumen. Cara tersebut antara lain memberikan promosi baik itu potongan harga atau diskon setiap bulannya.

Pra survei penelitian dilakukan untuk melihat karakteristik perilaku pembelian konsumen di Ramayana Mall Denpasar sebagai data pendukung. Pada waktu melakukan pra survei peneliti melakukan survei dengan cara wawancara langsung terhadap 30 responden secara acak tanpa melihat profil latar belakang dari ke 30 responden. Dari hasil survei terhadap 30 konsumen yang melakukan 
kegiatan belanja di Ramayana Mall Denpasar, didapat hasil pra survei penelitian seperti nampak pada Tabel 1.

Tabel 1.

Hasil Pra Survei Penelitian

Perilaku Pembelian di Ramayana Mall Denpasar

\begin{tabular}{llcc}
\hline No & \multicolumn{1}{c}{ Perilaku Pembelian } & Jumlah (orang) & Persentase (\%) \\
\hline 1. & $\begin{array}{l}\text { Saya tidak merencanakan barang yang } \\
\text { ingin dibeli sebelum berbelanja. }\end{array}$ & 4 & 13,3 \\
2. & $\begin{array}{l}\text { Saya membuat rencana pembelian } \\
\text { sebelum berbelanja tetapi membeli item } \\
\text { tambahan di luar perencanaan } \\
\text { sebelumnya }\end{array}$ & 9 & 30 \\
3. & & 56,7 \\
& $\begin{array}{l}\text { Saya membuat rencana pembelian } \\
\text { item tambahan di luar perencanaan } \\
\text { sebelumnya. }\end{array}$ & 17 & 100 \\
$\quad$ Total & 30 & \\
\hline Sumber: Data diolah, 2018 & &
\end{tabular}

Hasil pra survei penelitian yang dilakukan oleh penulis pada Maret 2018 terhadap 30 konsumen Ramayana Mall Denpasar menunjukkan bahwa konsumen Ramayana Mall Denpasar yang tidak merencanakan barang yang ingin dibeli sebelum berbelanja yaitu sebanyak 4 konsumen (13,3\%), merencanakan item yang ingin dibeli sebelum berbelanja tetapi membeli item tambahan yang tidak direncanakan sebelumnya yaitu sebanyak 9 konsumen (30\%), dan merencanakan item yang ingin dibeli sebelum berbelanja dan tidak menambah item tambahan diluar perencanaan sebelumnya yaitu sebanyak 17 konsumen $(56,7 \%)$. Hal ini menunjukkan bahwa konsumen tersebut tidak terpengaruh stimulus yang ditimbulkan oleh Ramayana Mall Denpasar untuk melakukan pembelian secara impulsif. Dalam rangka meningkatkan impulse buying, Ramayana Mall Denpasar perlu melakukan suatu pendekatan promosi yang tepat agar dapat merangsang impulse buying pada konsumen. Karena impulse buying akan mempengaruhi omset penjualan yang didapatkan. 
Lingkungan toko merupakan salah satu bagian dari bauran eceran yang memiliki arti yang sangat penting dalam menjalankan bisnis ritel. Dengan adanya lingkungan atau suasana toko yang baik, maka akan menarik pengunjung dan melakukan pembelian. Suasana toko adalah suatu karakteristik fisik yang sangat penting bagi setiap bisnis ritel hal ini berperan sebagai penciptaan susana yang nyaman sesuai dengan keinginan konsumen dan membuat konsumen ingin berlama-lama berada di dalam toko dan secara tidak langsung merangsang konsumen untuk melakukan pembelian.

Gilbert (2003) mendefinisikan suasana toko sebagai kombinasi dari pesan secara fisik yang telah direncanakan. Suasana toko dapat digambarkan sebagai perubahan tehadap perencanaan lingkungan pembelian yang menghasilkan efek emosional khusus yang dapat menyebabkan konsumen melakukan tindakan pembelian. Levi dan Weitz (2012) mendefinisikan suasana toko sebagai penciptaan suasana toko melalui visual, penataan, cahaya, musik dan aroma yang dapat menciptakan lingkungan pembelian yang nyaman sehingga dapat mempengaruhi persepsi dan emosi konsumen untuk melakukan pembelian. Utami (2006) mendefinisikan suasana toko sebagai kombinasi dari karakteristik fisik, seperti arsitektur, tata letak (display), pencahayaan, warna, temperatur, musik, serta aroma yang bertujuan untuk merancang respon emosional dan persepsi pelanggan dan untuk mempengaruhi pelanggan dalam membeli produk. Berdasarkan beberapa definisi suasana toko tersebut dapat disimpulkan suasana merupakan kegiatan yang dilakukan pemasar dengan mengkombinasikan beberapa elemen dalam rangka meningkatkan nilai estetika sebuah toko dan untuk 
memberikan rangsangan kepada konsumen agar bersedia berkunjung atau membeli.

Setiap toko agar dapat menarik konsumen dan pada akhirnya membeli produk dari toko harus mempunyai ciri khas tersendiri. Toko yang mempunyai ciri khas tersendiri akan gampang di kenal dan diingat oleh orang. Biasanya toko dapat menonjolkan ciri khas lewat karakteristik desainnya. Desain toko yang dapat mencerminkan produk-produk di dalam toko akan menimbulkan lingkungan yang nyaman, sehingga lebih meningkatkan ketertarikan konsumen untuk datang dan berbelanja di toko tersebut (William, 2013). Karakteristik lingkungan pencahayaan dan kebersihan menjadi salah satu hal yang penting dalam sebuah toko, karena konsumen akan merasa lebih tertarik untuk masuk kedalam toko. Lin and Yi (2010) menyatakan bahwa toko yang mampu menciptakan suasana yang nyaman akan menyebabkan pelanggan lebih cenderung untuk menikmati proses pembelian. Sebuah toko yang menarik tetapi tidak didukung dengan pelayanan dari karyawan toko yang kurang baik dapat membuat persepsi konsumen terhadap toko menjadi negatif. Konsumen dan produsen yang memiliki hubungan baik akan berpengaruh terhadap penjualan. Hubungan juga dapat mendukung tujuan pemasaran seperti kepuasan, loyalitas, dan kata positif dari mulut antara para konsumen (Hu dan Jasper, 2006). Hipotesis yang dapat dikembangkan :

$\mathrm{H}_{1}$ : Store environment memiliki pengaruh yang positif dan signifikan terhadap respon emosi positif.

Emosi positif didefinisikan sebagai suasana hati yang mempengaruhi dan menentukan intensitas pengambilan keputusan konsumen (Tirmizi et al, 2009). Keputusan pembelian konsumen didukung dengan keadaan emosi yang dirasakan 
konsumen pada saat itu juga. Konsumen dalam keadaan emosi yang positif cenderung mengalami lebih sedikit kompleksitas keputusan, keputusannya dalam waktu yang lebih singkat (Isen, 2014) dan lebih bersedia untuk menghabiskan lebih banyak waktu dan uang di toko (Donovan dan Rossiter, 2012). Hipotesis yang dapat dikembangkan :

$\mathrm{H}_{2}$ : Respon emosi positif memiliki pengaruh yang positif dan signifikan terhadap impulse buying.

Konsumen yang memiliki cukup waktu untuk berbelanja akan mengalami sedikit tekanan ketika memilih produk dan memberi perhatian lebih kepada lingkungan toko secara visual yang dapat menghasilkan rasa santai dan respon emosional positif saat berbelanja (Pierters \& Warlop, 1999). Hal ini dapat mendorong terjadinya pembelian impulsif. Sebaliknya, konsumen yang tidak memiliki cukup waktu untuk berbelanja akan mengurangi kesempatan untuk melakukan pembelian secara impulsif (Chang et al., 2013). Studi yang dilakukan oleh Gerht \& Yan (2004) menggunakan waktu untuk mengukur perspektif temporal karakteristik situasional, yang mengacu pada persepsi waktu yang tersedia untuk mempengaruhi konsumen saat berbelanja. Keputusan pembelian secara impulse mempunyai alasan mengapa mereka membeli produk tersebut. Misalnya, adanya potongan harga, barang yang dibeli menarik. penelitian yang dilakukan oleh Srivastava dan Kumar (2013) yang menemukan bahwa ketika konsumen memiliki lebih banyak uang ditangan untuk dibelanjakan, mereka cenderung merasa lebih positif dan bahagia. Ketersediaan uang memainkan peran fasilitator karena meningkatkan daya beli konsumen. Dengan demikian, konsumen dengan ketersediaan uang yang lebih akan merasa lebih bahagia dan 
bereaksi lebih positif terhadap perilaku pembelian secara impulsif, dibandingkan dengan mereka yang memiliki ketersediaan uang yang rendah (Chang et al., 2013). Chang et al. (2013) menemukan bahwa ketika berbelanja itu merupakan tugas tertentu, konsumen merasa bahagia terhadap pengalaman belanja mereka dan dengan demikian cenderung untuk melakukan pembelian secara impulsif. Hipotesis yang dapat dikembangkan :

$\mathrm{H}_{3}$ : Situational Factor memoderasi pengaruh respon emosi positif terhadap impulse buying.

\section{METODE PENELITIAN}

Penelitian ini dilakukan di Kota Denpasar, dengan alasan bahwa lokasi Ramayana Mall terletak di Denpasar, hal ini berarti terget pasar utama Ramayana adalah masyarakat Kota Denpasar. Banyaknya ritel modern yang ada di Denpasar membuat masyarakat mulai beralih pada ritel modern. Selain itu dilihat dari kepadatan penduduk Kota Denpasar lebih besar dibanding kota-kota lain di Bali dengan kepadatan penduduk mencapai 6.622 jiwa per-km² (https://denpasarkota.bps.go.id). Berdasarkan hal inilah peneliti memilih Kota Denpasar sebagai lokasi penelitian.

Populasi dalam penelitian ini adalah seluruh konsumen yang berbelanja di Ramayana Mall Denpasar.Jumlah indikator yang digunakan dalam penelitian iniadalah sebanyak 18 indikator sehingga banyak responden yang diambil sebagai sampel adalah $18 \times 5=90$ responden. Jadi responden yang diambil sebanyak 90 orang responden. 
Metode penentuan sampel pada penelitian ini bersifat tidak acak (nonrandom sampling) yaitu purposive sampling. Pengumpulan data yang digunakan dalam penelitian ini adalah kuisioner dan survei.

Tabel 2.

Operasional Variabel

\begin{tabular}{|c|c|c|c|}
\hline $\begin{array}{c}\text { Klasifikasi } \\
\text { Variabel }\end{array}$ & $\begin{array}{c}\text { Variabel } \\
\text { Penelitian }\end{array}$ & Indikator & Referensi \\
\hline Independen & $\begin{array}{c}\text { Store } \\
\text { Environment }(\mathrm{X} 1)\end{array}$ & $\begin{array}{l}\text { Penerangan }(\mathrm{X} 1.1) \\
\text { Warna }(\mathrm{X} 1.2) \\
\text { Musik (X1.3) } \\
\text { AromaRuangan (X1.4) }\end{array}$ & $\begin{array}{l}\text { Chang et al, } \\
\text { (2013), Levi dan } \\
\text { Weitz (2012) }\end{array}$ \\
\hline Pemoderasi & $\begin{array}{l}\text { Faktor Situasional } \\
\qquad(\mathrm{X} 2)\end{array}$ & $\begin{array}{l}\text { Ketersediaan waktu dalam } \\
\text { berbelanja (X2.1) } \\
\text { Tidak dalam tergesa-gesa saat } \\
\text { berbelanja (X2.2) } \\
\text { Memiliki uang lebih ketika } \\
\text { berbelanja (X2.3) } \\
\text { Bisa berbelanja secara royal } \\
\text { ketika menemukan sesuatu } \\
\text { yang dicari (X2.4) } \\
\text { Melakukan pembelian dalam } \\
\text { jumlah yang banyak (X2.5) } \\
\text { Berbelanja merupakan } \\
\text { kegiatan yang rutin (X2.6) }\end{array}$ & $\begin{array}{l}\text { Chang et al, } \\
\text { (2013), Beatty \& } \\
\text { Ferrel (1998) }\end{array}$ \\
\hline Dependen & $\begin{array}{l}\text { Emosi Positif } \\
\text { (Y1) }\end{array}$ & $\begin{array}{l}\text { Perasaan nyaman saat } \\
\text { berbelanja (Y1.1) } \\
\text { Perasaan puas saat berbelanja } \\
\text { (Y1.2) } \\
\text { Perasaan senang saat } \\
\text { berbelanja (Y1.3) } \\
\text { Perasaan antusias saat } \\
\text { berbelanja (Y1.4) }\end{array}$ & $\begin{array}{l}\text { Semuel Hatane } \\
(2006) \text {, Baron } \\
\text { dan Byrne, } \\
(2003)\end{array}$ \\
\hline Dependen & $\begin{array}{c}\text { Impulse Buying } \\
\text { (Y2) }\end{array}$ & $\begin{array}{l}\text { Membeli barang yang tidak } \\
\text { direncanakan sebelumnya } \\
\text { (Y2.1) } \\
\text { Membeli produk tanpa } \\
\text { berfikir panjang (Y2.2) } \\
\text { Perasaaan emosional } \\
\text { mempengaruhi kegiatan } \\
\text { berbelanja (Y2.3) } \\
\text { Sulit mengendalikan desakan } \\
\text { akibat penawaran yang } \\
\text { menarik (Y2.4) }\end{array}$ & $\begin{array}{l}\text { Kurniawan dan } \\
\text { Kunto (2013) }\end{array}$ \\
\hline
\end{tabular}

Sumber: Data diolah, 2018 
Analisis regresi linier sederhana digunakan untuk menguji pengaruh store environment terhadap respon emosi positif konsumen. Rumus analisis regresi linier sederhana adalah sebagai berikut (Sekaran, 2010).

$$
\mathrm{Y}_{1}=\mathrm{a}+\beta \mathrm{X} 1+\mathrm{e}
$$

Keterangan :

$$
\begin{array}{ll}
\text { Y1 } & \text { : Respon Emosi Positif } \\
\mathrm{a} & \text { : konstanta } \\
\beta & : \text { koefisien regresi } \\
\mathrm{X} 1 & : \text { Store Environment } \\
\mathrm{e} & : \text { standart error } \\
\alpha & : 0,05
\end{array}
$$

Analisis regresi moderasi digunakan untuk menguji peranan situational factor sebagai variabel yang memperkuat atau memperlemah intensitas pengaruh respon emosi positif terhadap perilaku impulse buying. Analisis yang digunakan dalam penelitian ini adalah analisis regresi dengan variabel moderasi atau Moderated Regression Analysis (MRA). Model regresi moderator dalam penelitian ini adalah sebagai berikut (Jogiyanto, 2010):

$$
\mathrm{Y}_{2}=\mathrm{a}+\beta_{2} \mathrm{Y}_{1}+\beta_{3} \mathrm{X}_{2}+\beta_{4} \mathrm{Y}_{1} * \mathrm{X}_{2}+\mathrm{e}
$$

Keterangan :

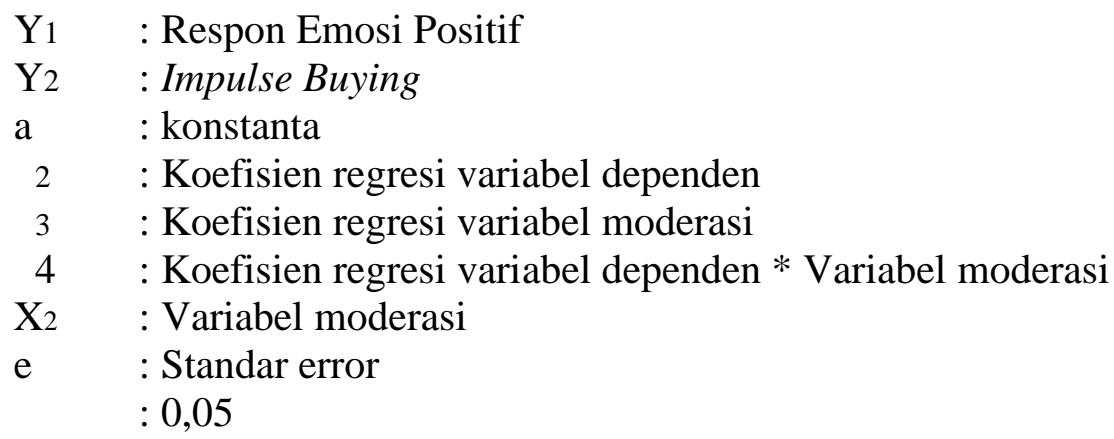




\section{HASIL PENELITIAN DAN PEMBAHASAN}

Responden dalam penelitian ini berjumlah 90 orang konsumen yang melakukan pembelian di Mall Ramayana sesuai dengan ukuran sampel yang digunakan. Responden penelitian digambarkan dengan menyajikan karakteristiknya berdasarkan variabel demografi yaitu jenis kelamin, usia, pendidikannya dan pekerjaan.

Tabel 3.

Karakteristik Responden

\begin{tabular}{|c|c|c|c|c|}
\hline No. & Variabel & Klasifikasi & Jumlah (orang) & Persentase \\
\hline \multirow{2}{*}{1} & \multirow{2}{*}{ Jenis Kelamin } & Laki - laki & 56 & 62,2 \\
\hline & & Perempuan & 34 & 37,8 \\
\hline & \multicolumn{2}{|c|}{ Jumlah } & 90 & 100 \\
\hline & & $17-23$ & 10 & 11,1 \\
\hline & & $24-30$ & 24 & 26,7 \\
\hline \multirow[t]{5}{*}{2} & Usia & $31-37$ & 32 & 35,6 \\
\hline & & $38-44$ & 19 & 21,1 \\
\hline & & $>44$ & 5 & 5,6 \\
\hline & & & 90 & 100 \\
\hline & \multirow{4}{*}{ Pendidikan } & SMA/SMK & 5 & 5,6 \\
\hline \multirow{6}{*}{3} & & Diploma & 27 & 41,1 \\
\hline & & $\mathrm{S} 1$ & 43 & 47,8 \\
\hline & & $\mathrm{S} 2 / \mathrm{S} 3$ & 5 & 5,6 \\
\hline & \multicolumn{2}{|c|}{ Jumlah } & 90 & 100 \\
\hline & & Pelajar & 10 & 11,1 \\
\hline & & Swasta & 15 & 16,7 \\
\hline \multirow[t]{3}{*}{4} & Pekerjaan & PNS & 36 & 40,0 \\
\hline & & Wiraswasta & 22 & 24,4 \\
\hline & & Lainnya & 7 & 7,8 \\
\hline \multicolumn{3}{|c|}{ Jumlah } & 90 & 100 \\
\hline
\end{tabular}

Sumber: Data diolah, 2018

Berdasarkan tabel 3 didapatkan hasil bahwa jumlah responden laki-laki yang melakukan pembelian di Ramayana Mall Denpasar lebih besar dari pada perempuan, yaitu sebanyak 56 orang atau 62,2 persen dari seluruh responden, sedangkan responden perempuan berjumlah 34 orang atau 37,8 persen dari seluruh responden. Data ini mencerminkan bahwa laki-laki tidak terlalu melihat merk barang yang dijual di Ramayana. Berbeda dengan perempuan yang pada saat menyebarkan kuisioner sebagian memberikan alasan bahwa barang-barang di 
Ramayana Mall Denpasar tidak cukup lengkap dan Branded, alasan lainnya dikarenakan laki-laki sebagian besar berbelanja sesuai kebutuhan sedangkan perempuan belanja sesuai diskon, dan pada waktu menyebar kuisoner pihak Ramayana Mall memberikan diskon tidak cukup besar pada waktu itu.

Berdasarkan klasifikasi usia, hasil penelitian ini menunjukkan bahwa responden berusia 31-37 tahun mendominasi dalam penelitian ini yaitu sebesar 35,6 persen dari seluruh responden di Kota denpasar. Data ini mencerminkan bahwa konsumen dengan rentang usia 31-37 tahun adalah yang paling aktif dalam hal berbelanja ke mal.

Berdasarkan karakteristik pendidikandidapatkan hasil bahwa dengan tingkat pendidikan S1 menempati urutan pertama konsumen yang melakukan pembelian di Ramayana Mall Denpasaryaitu sebanyak 43 orang atau 47,8 persen. Hal ini dikarenakan dalam kategori pendidikan, ini dianggap lebih bebas dalam memilih pakaian, menentukan warna, jenis dan bahan yang digunakan dalam bekerja maupun bepergian sehari-hari dan juga untuk bergaya up to date.

Kemudian berdasarkan pekerjaan, responden yang memiliki pekerjaan PNS mendominasi dalam penelitian ini dengan jumlah 36 orang atau dengan persentase sebesar 40 persen. Hal ini dikarenakan pegawai negeri sipil/PNS dianggap sudah memiliki penghasilan sendiri yang cukup dan cenderung lebih sering berbelanja di mal secara terencana maupun tidak terencana sebelumnya.

Variabel Store environment merupakan variabel bebas yang diukur dengan menggunakan 4 pernyataan yang berhubungan dengan Store environment pada 
Ramayana Mall Denpasar. Berdasarkan hasil penelitian dapat diketahui jawaban responden secara rinci pada Tabel 4.

Tabel 4.

Deskripsi Jawaban Responden Mengenai Variabel Store Environment

\begin{tabular}{|c|c|c|c|c|c|c|c|c|}
\hline \multirow{2}{*}{ No. } & \multirow{2}{*}{ Pernyataan } & \multicolumn{5}{|c|}{ Distribusi Jawaban } & \multirow{2}{*}{$\begin{array}{c}\text { Rata- } \\
\text { rata }\end{array}$} & \multirow[t]{2}{*}{ Kriteria } \\
\hline & & STS & TS & $\mathbf{N}$ & $\mathbf{S}$ & SS & & \\
\hline \multirow[t]{2}{*}{1.} & Penataan cahaya dalam gerai & 0 & 13 & 13 & 35 & 29 & 3.89 & \\
\hline & $\begin{array}{l}\text { Ramayana Mall Denpasar tampak } \\
\text { terang }\end{array}$ & & & & & & & Baik \\
\hline 2. & $\begin{array}{l}\text { Ramayana Mall Denpasar } \\
\text { memiliki dekorasi warna ruangan } \\
\text { yang menarik }\end{array}$ & 0 & 6 & 18 & 38 & 28 & 3.98 & Baik \\
\hline 3. & $\begin{array}{l}\text { Musik yang diputarkan dalam } \\
\text { gerai Ramayana Mall Denpasar } \\
\text { menimbulkan rasa nyaman saat } \\
\text { berbelanja }\end{array}$ & 0 & 8 & 21 & 34 & 27 & 3.89 & Baik \\
\hline \multirow[t]{2}{*}{4} & $\begin{array}{l}\text { Aroma dalam gerai Ramayana } \\
\text { Mall Denpasar menambah } \\
\text { kenyamanan saya berbelanja }\end{array}$ & 0 & 10 & 22 & 24 & 34 & 3.91 & Baik \\
\hline & \multicolumn{2}{|c|}{ Rata-Rata } & & & & & 3.92 & Baik \\
\hline
\end{tabular}

Sumber:Data diolah, 2018

Data pada Tabel 4 menunjukkan bahwa 4 pernyataan mengenai store environment pada Ramayana Mall Denpasar memperoleh nilai rata-rata sebesar 3,92 hal ini berarti konsumen yang merasakan store environment di Ramayana Mall Denpasar cukup tinggi. Nilai rata-rata tertinggi jawaban responden ditunjukkan pada pernyataan "Ramayana Mall Denpasar memiliki dekorasi warna ruangan yang menarik" dengan nilai rata-rata sebesar 3,98. Ini berarti responden merasa Ramayana Mall Denpasar memiliki dekorasi warna ruangan yang menarik. Selanjutnya, nilai rata-rata terendah jawaban responden ditunjukkan pada pernyataan "Penataan cahaya dalam gerai Ramayana Mall Denpasar tampak terang dan Saya merasa musik yang diputarkan dalam gerai Ramayana Mall Denpasar menimbulkan rasa nyaman saat berbelanja" dengan nilai rata-rata sebesar 3,89. 
Variabel situational factor merupakan variabel bebas yang diukur dengan menggunakan 6 pernyataan yang berhubungan dengan situational factor pada Ramayana Mall Denpasar. Berdasarkan hasil penelitian dapat diketahui jawaban responden secara rinci pada Tabel 5.

Tabel 5.

Deskripsi Jawaban Responden Mengenai Variabel Situational Factor

\begin{tabular}{|c|c|c|c|c|c|c|c|c|}
\hline \multirow{2}{*}{ No. } & \multirow{2}{*}{ Pernyataan } & \multicolumn{5}{|c|}{ Distribusi Jawaban } & \multirow{2}{*}{$\begin{array}{c}\text { Rata- } \\
\text { rata }\end{array}$} & \multirow[t]{2}{*}{ Kriteria } \\
\hline & & STS & TS & $\mathbf{N}$ & $\mathbf{S}$ & SS & & \\
\hline 1. & $\begin{array}{l}\text { Semakin lama berbelanja maka } \\
\text { semakin membuat merasa senang }\end{array}$ & 0 & 8 & 22 & 27 & 33 & 3.94 & Baik \\
\hline 2. & $\begin{array}{l}\text { Sewaktu pergi berbelanja, tidak } \\
\text { pernah tergesa-gesa saat membeli } \\
\text { barang }\end{array}$ & 0 & 10 & 18 & 30 & 32 & 3.93 & Baik \\
\hline 3. & $\begin{array}{ll}\text { Ketika membawa uang lebih } \\
\text { cenderung melakukan lebih } \\
\text { banyak pembelian }\end{array}$ & 0 & 11 & 22 & 26 & 31 & 3.86 & Baik \\
\hline 4 & $\begin{array}{l}\text { Ketika menemukan produk yang } \\
\text { dicari cenderung berbelanja } \\
\text { secara royal }\end{array}$ & 0 & 4 & 31 & 34 & 21 & 3.80 & Baik \\
\hline 5 & $\begin{array}{l}\text { Sering melakukan pembelian di } \\
\text { Ramayana Mall Denpasar dalam } \\
\text { jumlah yang banyak }\end{array}$ & 0 & 4 & 34 & 31 & 21 & 3.77 & Baik \\
\hline \multirow[t]{2}{*}{6} & $\begin{array}{l}\text { Sering berbelanja karena } \\
\text { merupakan kegiatan rutin }\end{array}$ & 0 & 14 & 21 & 25 & 30 & 3.79 & Baik \\
\hline & \multicolumn{2}{|c|}{ Rata-Rata } & & & & & 3.85 & Baik \\
\hline
\end{tabular}

Sumber :Data diolah, 2018

Data pada Tabel 5 menunjukkan bahwa 4 pernyataan mengenai situational factor memperoleh nilai rata-rata sebesar 3,85, hal ini berarti konsumen yang merasakan situational factor di Ramayana Mall Denpasar cukup tinggi. Nilai ratarata tertinggi jawaban responden ditunjukkan pada pernyataan "Semakin lama berbelanja maka semakin membuat saya merasa senang" dengan nilai rata-rata sebesar 3,94. Ini berarti responden merasa semakin lama berbelanja maka semakin membuat merasa senang. Selanjutnya, nilai rata-rata terendah jawaban responden ditunjukkan pada pernyataan "Sering melakukan pembelian di Ramayana Mall Denpasar dalam jumlah yang banyak" dengan nilai rata-rata sebesar 3,77. 
Variabel respon emosi positif merupakan variabel terikat yang diukur dengan menggunakan 4 pernyataan yang berhubungan dengan emosi positif konsumen pada Ramayana Mall Denpasar. Berdasarkan hasil penelitian dapat diketahui jawaban responden secara rinci pada Tabel 6.

\section{Tabel 6.}

Deskripsi Jawaban Responden Mengenai Variabel Respon emosi positif

\begin{tabular}{|c|c|c|c|c|c|c|c|c|}
\hline \multirow{2}{*}{ No. } & \multirow{2}{*}{ Pernyataan } & \multicolumn{5}{|c|}{ Distribusi Jawaban } & \multirow{2}{*}{$\begin{array}{l}\text { Rata- } \\
\text { rata }\end{array}$} & \multirow[t]{2}{*}{ Kriteria } \\
\hline & & STS & TS & $\mathbf{N}$ & $\mathbf{S}$ & SS & & \\
\hline 1. & $\begin{array}{l}\text { Merasa nyaman berbelanja di } \\
\text { Ramayana Mall Denpasar }\end{array}$ & 0 & 11 & 20 & 22 & 37 & 3.94 & Baik \\
\hline 2. & $\begin{array}{l}\text { Merasa puas ketika berbelanja di } \\
\text { Ramayana Mall Denpasar }\end{array}$ & 0 & 8 & 21 & 30 & 31 & 3.93 & Baik \\
\hline 3. & $\begin{array}{l}\text { Merasa senang saat berbelanja di } \\
\text { Ramayana Mall Denpasar }\end{array}$ & 0 & 5 & 22 & 33 & 30 & 3.98 & Baik \\
\hline 4 & $\begin{array}{l}\text { Merasa antusias ketika berbelanja } \\
\text { di Ramayana Mall Denpasar }\end{array}$ & 0 & 8 & 19 & 27 & 36 & 4.01 & Baik \\
\hline \multicolumn{3}{|c|}{ Rata-Rata } & & & & & 3.97 & Baik \\
\hline
\end{tabular}

Sumber:Data diolah, 2018

Data pada Tabel 6 menunjukkan bahwa 4 pernyataan mengenai respon emosi positif konsumen pada Ramayana Mall Denpasar memperoleh nilai ratarata sebesar 3,97, hal ini menunjukkan bahwa konsumen yang merasakan emosi positif di Ramayana Mall Denpasar cukup tinggi. Nilai rata-rata tertinggi jawaban responden ditunjukkan pada pernyataan "Merasa antusias ketika berbelanja di Ramayana Mall Denpasar" dengan nilai rata-rata sebesar 4,01. Ini berarti responden merasa antusias ketika berbelanja di Ramayana Mall Denpasar. Selanjutnya, nilai rata-rata terendah jawaban responden ditunjukkan pada pernyataan "Merasa puas ketika berbelanja di Ramayana Mall Denpasar" dengan nilai rata-rata 3,93.

Variabel impulse buying merupakan variabel terikat yang diukur dengan menggunakan 4 pernyataan yang berhubungan dengan impulse buying pada 
Ramayana Mall Denpasar. Berdasarkan hasil penelitian dapat diketahui jawaban responden secara rinci pada Tabel 7.

Tabel 7.

Deskripsi Jawaban Responden Mengenai Variabel impulse buying

\begin{tabular}{|c|c|c|c|c|c|c|c|c|}
\hline \multirow{2}{*}{ No. } & \multirow{2}{*}{ Pernyataan } & \multicolumn{5}{|c|}{ Distribusi Jawaban } & \multirow{2}{*}{$\begin{array}{l}\text { Rata- } \\
\text { rata }\end{array}$} & \multirow[t]{2}{*}{ Kriteria } \\
\hline & & STS & TS & $\mathbf{N}$ & $\mathbf{S}$ & SS & & \\
\hline 1. & $\begin{array}{l}\text { Sewaktu pergi berbelanja, sering } \\
\text { membeli barang-barang yang } \\
\text { tidak direncanakan sebelumnya. }\end{array}$ & 0 & 15 & 12 & 17 & 46 & 4.04 & Baik \\
\hline 2. & $\begin{array}{l}\text { Pernah membeli produk di } \\
\text { Ramayana Mall Denpasar tanpa } \\
\text { berfikir panjang }\end{array}$ & 0 & 6 & 22 & 28 & 34 & 4.00 & Baik \\
\hline 3. & $\begin{array}{l}\text { Perasaan emosional } \quad \text { yang } \\
\text { dirasakan mempengaruhi kegiatan } \\
\text { berbelanja di Ramayana } \\
\text { Denpasar }\end{array}$ & 0 & 14 & 16 & 27 & 33 & 3.88 & Baik \\
\hline 4 & \begin{tabular}{lrr}
\multicolumn{3}{l}{ Sulit mengendalikan diri terhadap } \\
desakan membeli produk & akibat \\
penawaran & menarik & yang \\
diberikan & Ramayana & Mall \\
Denpasar. & &
\end{tabular} & 0 & 10 & 21 & 28 & 31 & 3.89 & Baik \\
\hline & Rata-R & & & & & & 3.16 & $\begin{array}{l}\text { Cukup } \\
\text { Baik }\end{array}$ \\
\hline
\end{tabular}

Sumber:Data diolah, 2018

Data pada Tabel 7 dibawah menunjukkan bahwa 4 pernyataan mengenai impulse buying pada Ramayana Mall Denpasar memperoleh nilai rata-rata sebesar 3,16, hal tersebut menunjukkan bahwa konsumen pada Ramayana Mall Denpasar setuju untuk merasakan impulse buying yang tinggi. Nilai rata-rata tertinggi jawaban responden ditunjukkan pada pernyataan "Sewaktu pergi berbelanja, saya sering membeli barang-barang yang tidak direncanakan sebelumnya." dengan nilai rata-rata sebesar 4,04. Ini berarti responden pada waktu pergi berbelanja, mereka sering membeli barang-barang yang tidak direncanakan sebelumnya. Selanjutnya, nilai rata-rata terendah jawaban responden ditunjukkan pada 
pernyataan "Perasaan emosional yang dirasakan mempengaruhi kegiatan berbelanja di Ramayana Mall Denpasar" dengan nilai rata-rata sebesar 3,88.

Model analisis regresi linear sederhana digunakan untuk mendapat koefisien regresi yang akan menentukan apakah hipotesis yang dibuat akan diterima atau ditolak. Hasil analisis ini mengacu pada hasil pengaruh store environment terhadap respon emosi positif pada konsumen Ramayana Mall Denpasar. Adapun hasil analisis regresi dengan program Statitical Pacage of Social Science (SPSS) versi 22.0 for Windows dapat dilihat pada hasil perhitungan di bawah ini.

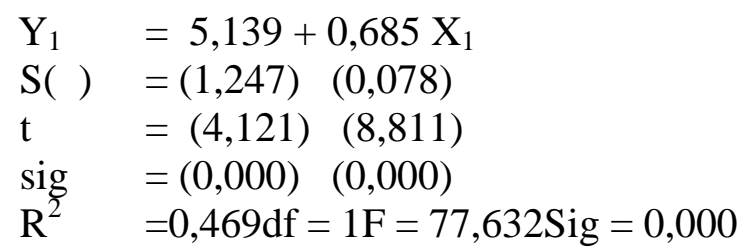

Hasil perhitungan $\mathrm{F}$ menunjukkan angka sebesar 77,632, dengan nilai signifikan sebesar $0,000<0,05$ yang berarti bahwa variable store environment berpengaruh terhadap emosi positif dan layak diujikan dalam penelitian ini.

Koefisien determinasi atau $\mathrm{R}^{2}$ sebesar 0,469 yang berarti bahwa sebesar $46,9 \%$ variable emosi positif dipengaruhi oleh store environment. Sisanya 53,1\% dijelaskan oleh faktor lain diluar model ini.

Dari angka-angka tersebut dapat dijelaskan bahwavariabelstore environment berpengaruh positif terhadap respon emosi positif pada konsumen Ramayana Mall Denpasar, dengan kata lain apabila store environment mengalami peningkatan maka emosi positif pada konsumen Ramayana Mall Denpasar akan meningkat. 
Pengujian ini bertujuan untuk menguji hubungan antara pengaruh antara satu variabel independen dengan dependen. Uji ini digunakan untuk mengetahui pengaruh respon emosi positif $\left(\mathrm{Y}_{1}\right)$ yang di moderasi oleh situational factor $(\mathrm{X} 2)$, pada impulse buying pada konsumen Ramayana Mall Denpasar (Y2). Hasil pengujian Moderated Regression Analysis (MRA) dapat dilihat pada hasil perhitungan di bawah ini.

$$
\begin{array}{ll}
\mathrm{Y}_{2} & =15,420+2,237 \mathrm{Y}_{1}+1,465 \mathrm{X}_{2}+1,146 \mathrm{Y}_{1} \mathrm{X}_{2} \\
\mathrm{~S}(\beta) & =(2,237)(1,465)(1,1146) \\
\mathrm{t} & =(9,472)(5,599)(3,631) \\
\operatorname{sig} & =(0,000)(0,000)(0,000) \\
\mathrm{R}^{2} & =0,904 \mathrm{df}=3 \mathrm{~F}=270,472 \mathrm{Sig}=0,000
\end{array}
$$

Hasil perhitungan $\mathrm{F}$ menunjukkanangka sebesar 270,472 dengan nilai signifikan sebesar $0,000<0,05$ yang berarti bahwa variable store environment berpengaruh terhadap emosi positif dan layak diujikan dalam penelitian ini.

Koefisien determinasi atau $\mathrm{R}^{2}$ sebesar sebesar 0,904 . Hal ini berarti bahwa sebesar 90,4\% variabel impulse buying dijelaskan oleh store environment, respon emosi positif dan situational factor. Sisanya sebesar 0,6\% dijelaskan oleh variabel lain di luar model penelitian ini.

Pada pengujian hipotesis yang pertama dapat dilihat dari hasil uji dimana memiliki hasil uji signifikan $\mathrm{t}$ sebesar $0,000(0,000<0,05)$ maka $\mathrm{H}_{0}$ ditolak, artinya ada pengaruh variabel Store environment memiliki pengaruh yang positif dan signifikan terhadap respon emosi positif.Koefisien regresi $\mathrm{X}_{1}$ sebesar 0,685, menunjukkan bahwa meningkatnya Store Environment maka akan meningkatkan respon emosi positif. Hasil penelitian ini mendukung hipotesis pertama yaitu 
Store Environment memiliki pengaruh yang positif dan signifikan terhadap respon emosi positif. Hasil penelitian ini sesuai dengan penelitian yang dilakukan oleh Lin and Yi (2010) menyatakan bahwa toko yang mampu menciptakan suasana yang nyaman akan menyebabkan pelanggan lebih cenderung untuk menikmati proses pembelian. Sebuah toko yang menarik tetapi tidak didukung dengan pelayanan dari karyawan toko yang kurang baik dapat membuat persepsi konsumen terhadap toko menjadi negatif. Konsumen dan produsen yang memiliki hubungan baik akan berpengaruh terhadap penjualan. Hubungan juga dapat mendukung tujuan pemasaran seperti kepuasan, loyalitas, dan kata positif dari mulut antara para konsumen (Hu dan Jasper, 2006).

Pada pengujian hipotesis yang kedua dapat dilihat dari hasil uji dimana memiliki hasil uji signifikan t sebesar 0,000 $(0,000<0,05)$ maka $\mathrm{H}_{0}$ ditolak, artinya ada pengaruh variabel Respon emosi positif yang positif dan signifikan terhadap impulse buying. Koefisien regresi $\mathrm{Y}_{1}$ sebesar 2,237, menunjukkan bahwa meningkatnya respon emosi positif maka akan meningkatkan impulse buying. Hasil penelitian ini mendukung hipotesis kedua yaitu respon emosi positif memiliki pengaruh yang positif dan signifikan terhadap impulse buying. Hasil penelitian ini sesuai dengan penelitian yang dilakukan oleh Tirmizi et al. (2009). Keputusan pembelian konsumen didukung dengan keadaan emosi yang dirasakan konsumen pada saat itu juga. Konsumen dalam keadaan emosi yang positif cenderung mengalami lebih sedikit kompleksitas keputusan, keputusannya dalam waktu yang lebih singkat (Isen, 2014) dan lebih bersedia untuk menghabiskan lebih banyak waktu dan uang di toko (Donovan dan Rossiter, 2012). 
Pada pengujian hipotesis yang kedua dapat dilihat dari hasil uji dimana memiliki hasil uji signifikan $\mathrm{t}$ sebesar $0,000(0,000<0,05)$ maka $\mathrm{H}_{0}$ ditolak, artinya ada pengaruh situational factor memoderasi/memperkuat pengaruh respon emosi positif terhadap impulse buying. Koefisien regresi $\mathrm{Y}_{1} \mathrm{X}_{2}$ sebesar 1,146, menunjukkan bahwa dengan adanya situational factor pengaruh respon emosi positif terhadap impulse buying akan semakin diperkuat. Hasil penelitian ini mendukung hipotesis ketiga yaitu Situational factor memoderasi pengaruh Respon emosi positif terhadap impulse buying. Hasil penelitian ini sesuai dengan penelitian yang dilakukan oleh Gerht \& Yan (2004) menggunakan waktu untuk mengukur perspektif temporal karakteristik situasional, yang mengacu pada persepsi waktu yang tersedia untuk mempengaruhi konsumen saat berbelanja. Keputusan pembelian secara impulse mempunyai alasan mengapa mereka membeli produk tersebut. Misalnya, adanya potongan harga, barang yang dibeli menarik. Penelitian yang dilakukan oleh Srivastava dan Kumar (2013) yang menemukan bahwa ketika konsumen memiliki lebih banyak uang ditangan untuk dibelanjakan, mereka cenderung merasa lebih positif dan bahagia. Ketersediaan uang memainkan peran fasilitator karena meningkatkan daya beli konsumen. Dengan demikian, konsumen dengan ketersediaan uang yang lebih akan merasa lebih bahagia dan bereaksi lebih positif terhadap perilaku pembelian secara impulsif, dibandingkan dengan mereka yang memiliki ketersediaan uang yang rendah (Chang et al., 2013). Namun penelitian yang dilakukan Tanuwijaya dan Ellyawati (2017) menyatakan kalau peran situational factor juga dapat memoderasi tetapi memperlemah pengaruh respon emosi positif terhadap 
pembelian tak rencana atau impulse buying. Salah satu faktor situasional konsumen yang mempengaruhi tidak terjadinya impulse buying dikarenakan ketersediaan uang/finansial yang kurang pada saat berbelanja, hal tersebut membuat emosi positif tidak tumbuh dengan baik pada saat berbelanja yang mengakibatkan tidak terjadinya impulse buying. Secara umum, konsumen memiliki uang yang lebih banyak pada saat awal-awal bulan atau tanggal muda (memperoleh gaji atau uang saku). Pada saat itu adalah saat yang baik untuk memberikan stimuli bagi konsumen untuk berbelanja dengan lebih impulsif. Cara yang dapat dilakukan adalah dengan membuat program promosi penjualan (diskon, potongan harga, dan lain sebagainya) untuk meningkatkan kunjungan belanja konsumen di bisnis ritel maupun meningkatkan pembelian tanpa rencana.

\section{SIMPULAN DAN SARAN}

Store environment memiliki pengaruh yang positif dan signifikan terhadap respon emosi positif, yang artinya meningkatnya store environmentmaka akan meningkatkan respon emosi positif konsumen di Ramayana Mall Denpasar.

Respon emosi positif memiliki pengaruh yang positif dan signifikan terhadap perilaku impulse buying, yang artinya meningkatnya respon emosi positif maka akan meningkatkanimpulse buyingkonsumendiRamayana Mall Denpasar

Situational Factor memoderasi/memperkuat pengaruh respon emosi positif terhadap impulse buying, yang artinya dengan adanya situational factor pengaruh respon emosi positif terhadap impulse buying konsumen akan semakin diperkuat.

Saran-saran yang dapat diberikan adalah pihak Ramayana Mallhendaknya memperhatikan penataan cahaya terhadap gerai-gerai yang ada, dan 
memperhatikan musik yang diputar agar sesuai dengan nuansa yang ada untuk meningkatkan pengambilankeputusan pembelian tanpa rencana atau impulse buying.

Pihak Ramayana Mall diharapkan memperbaiki sistem pelayanan karena dengan memperhatikan sistem pelayanan yang ada, konsumen pun merasa betah dalam melakukan pembelian di mall, hal ini bisa meningkatkan impulse buying konsumen yang berbelanja di Ramayana Mall Denpasar.

Dalam penelitian dimasa mendatang perlu dipertimbangkan untuk menggunakan variabel lain yang dapat mempengaruhi impulse buying sepertihedonic factor, promosi penjualan mengingat dalam hal ini suatu promosi penjualan sangatlah erat keterkaitannya dengan impulse buying.

Memperluas cakupan wilayah penelitian misalnya dengan mengambil lokasi di mall lain yang ada di Bali atau Indonesia sehingga penelitian dapat digeneralisasikan.

\section{REFERENSI}

Astuti, R. D., dan Fillipa, M. (2008). Perbedaan pembelian secara impulsif berdasarkan tingkat kecenderungan, kategori produk dan pertimbangan pembelian, Jurnal Ichsan Gorontalo, 3 (1), 1441-1456.

Baron, R.A., dan Byrne, D. (2003). Psikologi Sosial. Penerbit: Erlangga, Jakarta.

Chang, H.J., Yan, R-N., \& Eckman, M. (2013). Moderating effects of situasional characteristics on impulse buying. Internastional Journal of Retail \& Distribution management, 42. 298 - 133314. Doi 10.1108/IJRDM-042013-0074.

Coley, A. And Burgess, B. (2003). Gender differences in cognitive and affective impulse buying. Journal of Fashion Marketing and Management, 7 (3), 282-295.

Donovan R. J. dan J. R. Rossiter. (2012). Store Atmosphere: An Environment Psychology Approach, Journal of Retailing, 58 (1), 210-220. 
Gilbert, D. (2003).Retailing Marketing Management. England, Endinburgh Gate: Pearson Educated Limited.

Hausman, A. (2000). A multi-method investigation of consumer motivations in impulse buying behaviour. Journal of Consumer Marketing, 17 (5), 403419.

Herabadi, A. G. (2003). Buying Impulse: A Study on Impulsive Consumption, Disertasi, Social Psychological Departement, Catholic University of Nijmegen, Belanda.

Hu, H. and Jasper, C.R. (2006). "Social cues in the store environment and their impact on store image", International Journal of Retail and Distribution Management, 40 (4), 273-289.

Isen, A, (2014) The Influences of Positive Affect on Decision-Making and Cognitive Organization, Advances in Consumer Research, 11, 2014.

Jogiyanto, 2010. Analisis dan Desain Sistem Informasi, Edis IV, Andi Offset, Yogyakarta.

Kurniawan, D. Dan Y. S. Kunto. (2013).Pengaruh Promosi dan Store Atmosphere Terhadap Impuls buying dengan Shoping Emotion Sebagai Variabel Intervening Studi Kasus di Matahari Departement Store Cabang Supermall Surabaya. Jurnal Manajemen Pemasaran 1 (2), 1-8.

Levi, M., dan Weitz, B. (2012).Retailing Management. International Edition. Edisi 4 New York: McGraw-Hill.

Lin, Miao-Que and Yi-Fang Chiang. (2010). The Influence of Store Environment on Perceived Experiental Value and Behavior Intention. Asia Pacific Management Review, 15(2), 281-299.

Mohan, G., Sivakumaran, B. and Sharma, P. (2013). "Impact of store environment on impulse buying behaviour", European Journal of Marketing, 47 (10), $1-33$.

Negara, D. J. \& Dharmmesta, B. S. (2003). Normative Moderators of Impulse Buying Behavior, Gadjah Mada International Journal of Business, 5 (1), 1-14.

Octaprinanta, N., Kumadji, S \& Hidayat, K. (2013). Pengaruh Faktor Situasional Terhadap Emotional States dan Impulse Buying (Survey pada Pengunjung Giant Hypermarket Mall Olympic Garden Malang). Jurnal Aplikasi Manajemen, 9 (4): 88-96.

Sekaran, Uma., dan Roger Bougie. (2010). Edisi 5, Research Method For Business: A Skill Building Approach. John Wiley @ Sons, New York. 
Semuel, H. (2005). Respon lingkungan berbelanja sebagai stimulus pembelian tidak terencana pada toko serba ada (toserba): studi kasus carrefour Surabaya, Jurnal Manajemen dan Kewirausahaan, 7 (2), 152-170.

Sharma, P., Sivakumaran, B., \& Marshall, R. (2010). Impulse buying and Variety seeking: A trait-correlates perspective. Journal of Business Research, 63, 27-83.

Srivastava, S., dan Manish, K. (2013). Evaluating Effective Situational Factor on Consumer Impulse Buying. International Journal of Applied Research \& Studies, 2 (3). 220-229.

Susanta. (2007). Majalah Marketing/EDISI KHUSUS/II. Jakarta.

Tanuwijaya S.D., dan Ellyawati J. (2017). Pengaruh Karakteristik Lingkungan Toko Dan Perilaku Positif Emosional Konsumen TerhadapPerilaku Impulse Buying: Pengujian Efek Moderasi Faktor Situational. 1-15. ISSN

Tirmizi, et al. (2009). An Empirical Study of Consumer Impulse Buying Behaviour In Local Markets. European Journal of Scientific Research. 28 (4), 522-532.

Utami, C.W. (2006).Manajemen Ritel:Strategi dan Implementasi Operasional Bisnis Ritel Modern di Indonesia. Penerbit: Salemba Empat, Jakarta.

William, Jebarajakirthy. (2013). "Significant Of Visual Merchandising As A weapon Of Strategic Marketing: In Sri Lanka Food Retailing", International Journal of Management Research and Review, 3(3), 23552363. 